\title{
Cognitive abilities, psychological motives, and social interactions as components of long-term learning in basic electricity
}

K. Grob, C.-V. Rhôneck et B. Vôlker

\section{(2) OpenEdition \\ Journals \\ Édition électronique \\ URL : http://journals.openedition.org/trema/2316 \\ DOI : $10.4000 /$ trema.2316 \\ ISSN : 2107-0997 \\ Éditeur \\ Faculté d'Éducation de l'université de Montpellier}

Édition imprimée

Date de publication : 1 mai 1993

Pagination : 27-35

ISSN : 1167-315X

\section{Référence électronique}

K. Grob, C.-V. Rhôneck et B. Vôlker, « Cognitive abilities, psychological motives, and social interactions as components of long-term learning in basic electricity », Tréma [En ligne], 3-4 | 1993, mis en ligne le

01 mai 1993, consulté le 21 avril 2019. URL : http://journals.openedition.org/trema/2316 ; DOI :

10.4000/trema.2316

Ce document a été généré automatiquement le 21 avril 2019.

Trema 


\title{
Cognitive abilities, psychological motives, and social interactions as components of long-term learning in basic electricity
}

\author{
K. Grob, C.-V. Rhôneck et B. Vôlker
}

\section{Introduction}

1 Since research in learning and instruction turns back to the process of understanding, the learning of the student is seen as an active process of know-ledge construction. In this context learning means "to develop understanding" or "to know something well that was unknown before". This process can only be studied in a specific knowledge domain. In our case, students' conceptions, concepts and rules in physics, and integrated knowledge of the circuit as a system belong to the specific knowledge domain.

2 If in this first approximation the cognitive aspects of learning are emphasized, learning should not be seen as a process without emotions. It is a principle of learning psychology that cognitive and motivational processes are intermixed, when learning takes place. The handy formulation of "will and skill" (Salomon 1987) describes this evident fact.

Besides cognitive actions and motivational states it is important for the learning of the student how he or she perceives the environment. It ranges from more distal cultural and social influences to the proximal social interactions with teachers and class-mates, which define the social climate in the classroom. Especially, in the case of long-term learning the class climate influences the learning processes. 


\section{The study}

During the last two years a study was carried out which aimed at describing the development of the knowledge structures and the interaction between learning and its cognitive, motivational and social conditions. The study was carried out in five classes (grade 8, Realschule) for about three quarters of a year. The results of this study depend on the teaching method used. It may be described as follows : At a first stage the concepts and rules used in physics are presented with the emphasis on correct and clear information. The teacher and the students discuss those situations systematically where in general conflicts arise between the everyday meaning of concepts and their meaning in physics, or between students' conceptions and a correct description of the processes in the electric circuits.

5 For us, the development of a correct view of the processes in the electric circuit is very important. For that reason we check the concepts and rules as well as the integration of their components with exercise tests parallel to instruction and in addition with a special test, called intermediate test. No marks are given in these tests. In the following problemsolving sessions a supportive climate is offered in which students are given the opportunity to practice and integrate the concepts and rules that will initiate conceptual change. At the last stage of the unit just before the final class test is presented, teacher support is faded to improve autonomous problem-solving. The psychological factors and the learning results were measured on the basis of the following tests. Data were collected on:

- Study habits and attitudes (Thiel et al. 1979). Some of the 20 variables of the test may be quoted : In the domain of motivation we find four variables success orientation, failure orientation, the dichotomic extrinsic vs. intrinsic motivation and self-esteem which may be achievement oriented or multi-thematic. The proper study habits and attitudes comprise assimilation of subject matter, phase of actualization (disturbed vs. undisturbed), learning style and achievement control. The reactions to lack of success are described by tolerance of failure and resistance to stress. The influence of the pedagogical environment is measured inter alias by variables like learning behavior and attitude toward school.

- The development of formal operations [Piaget test (Lawson 1978)]. This test presents 15 demonstration items that illustrate problems from physics. Finding solutions to the problems involves problem-solving strategies, which are interpreted in the context of Piagets's theory of cognitive development.

- Interest in electricity (Häussler 1987).

- Invested effort of the student during the course and during the preparation of the final class test [see AIME (Salomon 1987)].

- Climate of the class-room (von Saldern 1987). This test comprises three aspects : the interaction between student and teacher, between student and student and the perception of instruction. The main variables for teacher-student-interaction are thoughtfulness of the teacher, authoritarian style of leadership and aggression against the teacher. The studentstudent-interaction is described by cliqueness, helpfulness, aggression against class-mates, discrimination of class-mates and satisfaction with class-mates. The general characteristics 
of instruction comprise among other variables order and organization and reduced participation in instruction.

6

\section{Also included in our evaluation were}

- Exercise tests, which describe students' spontaneous grasp of information about scientific concepts and rules. No marks were given.

- The results of an intermediate test. This test combined test items related to several concepts and rules. No marks were given.

- The results of a class test. The test covered the content of the teaching unit.

- The results of a retention test. This test recapitulated the problems of the inter-mediate test with similar items two month after the class test. Again no marks were given.

7 Finally, data in form of school marks were collected on the students' ability in mathematics, biology, German language and English language in the previous school year. In the following, we will try to put these different aspects together for a better understanding of the learning processes in the class-room.

\section{Results}

The most important correlations between psychological and achievement variables are presented in the correlation matrix of table 1 for the pool ( $\mathrm{N}=123$ students).

9 The matrix of variables shows that increasing abilities (Piaget test, marks), better study habits and attitudes (motivation oriented to failure with negative sign, learn-ing style oriented toward basics, positive attitude toward school), and a positive climate of the class-room lead to better achievements. The positive and negative signs in the correlation matrix are stable all over the teaching unit and correspond to the expectations. The correlations of table 1 give rise to a package of statements, why some students learn and others do not. But these statements are on a general level. Therefore we analyze the correlations in detail for special subgroups of students. 
Table 1 : Significant correlations between achievement in physics, ability, study habits and attitudes, and climate of the class-room (grade 8 , five classes, $N=123$ ). Significance $*: 0.01$, $* *$ : 0.001 .

\begin{tabular}{|c|c|c|c|c|}
\hline & $\begin{array}{c}\text { Exercise } \\
\text { tests }\end{array}$ & $\begin{array}{c}\text { Intermed. } \\
\text { test }\end{array}$ & $\begin{array}{c}\text { Class } \\
\text { test }\end{array}$ & $\begin{array}{c}\text { Retention } \\
\text { test }\end{array}$ \\
\hline Marks & $0.35^{* *}$ & $0.31^{* *}$ & $0.35^{* *}$ & $0.38^{* *}$ \\
\hline Piaget test & $0.32^{* *}$ & $0.27^{*}$ & $0.42^{* *}$ & $0.44^{* *}$ \\
\hline Motivation (failure orientation) & $-0.26^{*}$ & -0.17 & $-0.23^{*}$ & $-0.27^{* *}$ \\
\hline Learning style (facts vs. basics) & 0.12 & 0.16 & $0.25^{*}$ & 0.16 \\
\hline Attitude toward school & 0.05 & 0.21 & $0.26^{*}$ & 0.19 \\
\hline Aggression against teacher & -0.20 & -0.05 & $-0.25^{*}$ & $-0.43^{* *}$ \\
\hline Cliqueness & -0.22 & -0.19 & $-0.24^{*}$ & -0.39 ** \\
\hline Helpfulness & 0.12 & 0.20 & 0.23 & $0.34^{* *}$ \\
\hline Discrimination of class-mates & -0.23 & $-0.33^{* *}$ & $-0.30^{*}$ & $-0.53^{* *}$ \\
\hline Satisfaction with class-mates & $0.26^{*}$ & $0.32^{*}$ & $0.30^{*}$ & $0.48^{* *}$ \\
\hline Aggression against class-mates & $-0.24^{*}$ & $-0.28^{*}$ & $-0.26^{*}$ & $-0.47^{* *}$ \\
\hline Order and organisation & -0.21 & -0.20 & -0.21 & $-0.34^{* *}$ \\
\hline
\end{tabular}

10 The categories for the definition of subgroups may be chosen freely. Of course, the categories should be oriented toward approved classifications. Gender differences (Kotte 1992), differences for students in rural and urban classes (von Rhöneck and Grob 1991), and achievers vs. non-achievers are such categories. From experience in an earlier study we learned (von Rhöneck and Grob 1989) that in the first stage of instruction the conceptions of the students may bifurcate in two directions : some students develop a correct understanding, whereas the rest tends to an alternative view of the processes in an electric circuit. That gave us the idea to analyze the learning processes very carefully during the first half of the teaching unit. Here exercise tests and intermediate test document the learning processes. As an instrument for the analysis we used a cluster analysis. By means of this analysis we isolated two well separated groups, which we call continuous and sporadic learners. Continuous learners show a steady learning behavior, sporadic learners concentrate their learning activities on the preparations for the class test.

The groups of continuous and sporadic learners may be divided in subgroups for girls and boys. This partition is confirmed by the specific profiles and the characteristic correlations for the subgroups. As an example, we interprete the differences of the means in special variables for two subgroups: the continuously learning girls and boys (see figure 1). 
Figure 1 : The deviation from the means in standard deviations for the subgroups of continuous learners : girls and boys.

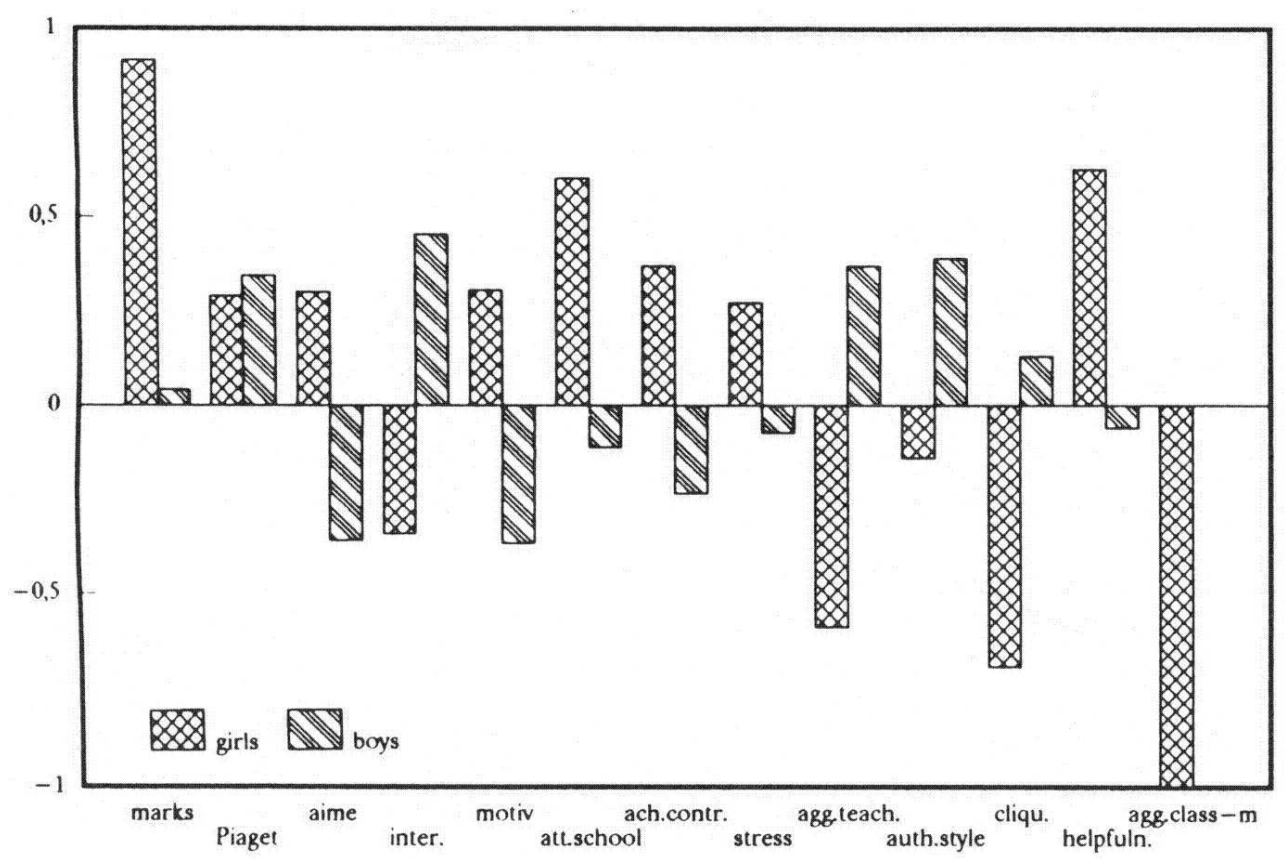

The group of girls is characterized by good marks, a certain amount of effort (aime) and no interest in basic electricity. The motivation is more intrinsic and the attitude toward school is good. Achievement control and resistance to stress are typical of them. There is no aggression against the teacher, and an authoritarian style of leadership is not mentioned. Cliqueness and aggression against class-mates seem to be no problem, and their helpfulness seems to be high.

The boys use a totally different approach for learning basic electricity. They learn without effort (aime), but their interest is high. The motivation is more extrinsic. Achievement control and stress resistance are not prominent. They indicate aggression against the teacher and they impute to the teacher an authoritarian style of leadership.

A second argument for the partition into subgroups results from the means for different tests in physics (see table 2). The rather small differences in the exercise tests accumulate to large differences in the intermediate test. These differences are only partly reduced in the class test, which reflects the systematic activities of the sporadic learners.

Table 2 : The means of different tests in physics for four subgroups in relation to the results in the pool.

\begin{tabular}{|c|c|c|c|c|}
\hline & $\begin{array}{c}\text { Exercise } \\
\text { tests }\end{array}$ & $\begin{array}{c}\text { Intermed. } \\
\text { test }\end{array}$ & $\begin{array}{c}\text { Class } \\
\text { test }\end{array}$ & $\begin{array}{c}\text { Retention } \\
\text { test }\end{array}$ \\
\hline Continuous learners (girls) & 106 & 140 & 120 & 133 \\
\hline Continuous learners (boys) & 113 & 155 & 129 & 127 \\
\hline Sporadic learners (girls) & 92 & 69 & 73 & 77 \\
\hline Sporadic learners (boys) & 96 & 69 & 96 & 86 \\
\hline
\end{tabular}


Even more instructive than means are the correlations between the variables, which provide information about successful and unsuccessful students in the subgroups. We start with the female group of continuous learners in table 3 :

Table 3 : The most important correlations between achievement in physics, ability, study habits and attitudes, and climate of the class-room for the female group of the continuous learners $(N=21)$.

\begin{tabular}{|lcccc|}
\hline & \multicolumn{2}{c}{ Exercise } & Intermed & \multicolumn{2}{c|}{ Class } & Retention \\
& tests & test & test & test \\
\hline Marks & $0.65^{*}$ & 0.38 & $0.72^{* *}$ & $0.54^{*}$ \\
Piaget test & 0.44 & 0.01 & 0.49 & 0.44 \\
\hline Motivation (extrinsic vs. intrinsic) & $-0.53^{*}$ & $-0.55^{*}$ & 0.45 & 0.48 \\
Motivation (failure orientation) & $0.53^{*}$ & -0.23 & -0.36 & -0.41 \\
Tolerance of failure & $0.63^{*}$ & 0.43 & 0.31 & $0.56^{*}$ \\
Resistance to stress & 0.34 & 0.22 & 0.29 & $0.55^{*}$ \\
\hline Thoughtfulness of the teacher & -0.36 & -0.32 & $-0.52^{*}$ & -0.36 \\
Aggression against teacher & -0.45 & -0.03 & $-0.58^{*}$ & $-0.56^{*}$ \\
Discrimination of class-mates & -0.40 & -0.23 & -0.57 & $-0.71^{* *}$ \\
\hline
\end{tabular}

The characteristic aspects of this correlation matrix is primarily found in the second block of variables: In this subgroup motivation (intrinsic motivation, failure oriented motivation [negative sign]) and mastering of difficulties (tolerance of failure, resistance to stress) enable us to differentiate between successful and unsuccessful learners.

In the male group of the continuous learners we find another mixture of variables in the second block of the matrix (see table 4) :

Multi-thematic self-esteem and a type of learning behavior that depends on interest describe the successful learners in this group. They are good learners when they are not concentrated on school achievement and when their effort depends on interest.

Table 4 : The most important correlations between achievement in physics, ability, study habits and attitudes, and climate of the class-room for the male group of the continuous learners $(N=27)$.

\begin{tabular}{|c|c|c|c|c|}
\hline & $\begin{array}{c}\text { Exercise } \\
\text { tests }\end{array}$ & $\begin{array}{c}\text { Intermed. } \\
\text { test }\end{array}$ & $\begin{array}{c}\text { Class } \\
\text { test }\end{array}$ & $\begin{array}{c}\text { Retention } \\
\text { test }\end{array}$ \\
\hline Marks & $0.55^{*}$ & 0.17 & 0.34 & $0.51^{*}$ \\
\hline Piaget test & 0.23 & 0.15 & $0.58^{* * *}$ & 0.42 \\
\hline $\begin{array}{l}\text { Self-esteem } \\
\text { (achivement orient. vs. multithematic) }\end{array}$ & 0.30 & 0.25 & 0.33 & $0.46^{*}$ \\
\hline $\begin{array}{l}\text { Learning behavior } \\
\text { (interest depend. vs. interest indep.) }\end{array}$ & -0.10 & -0.06 & $-0.46^{*}$ & -0.40 \\
\hline
\end{tabular}




\begin{tabular}{|c|c|c|c|c|}
\hline & $\begin{array}{c}\text { Exercise } \\
\text { tests }\end{array}$ & $\begin{array}{c}\text { Intermed. } \\
\text { test }\end{array}$ & $\begin{array}{c}\text { Class } \\
\text { test }\end{array}$ & $\begin{array}{c}\text { Retention } \\
\text { test }\end{array}$ \\
\hline Aggression against teacher & -0.29 & -0.12 & $-0.55^{*}$ & $-0.63^{* * *}$ \\
\hline Cliqueness & -0.40 & -0.08 & $-0.45^{*}$ & $-0.59^{* * *}$ \\
\hline Helpfulness & 0.12 & 0.15 & $0.47^{*}$ & $0.53^{*}$ \\
\hline Discrimination of class-mates & -0.15 & -0.09 & $-0.52^{*}$ & $-0.68^{* * *}$ \\
\hline Satisfaction with class-mates & 0.21 & 0.16 & 0.39 & $0.52^{*}$ \\
\hline Aggression against class-mates & -0.02 & 0.12 & -0.19 & $-0.50^{* *}$ \\
\hline Discipline and order & -0.44 & -0.08 & $-0.52^{*}$ & $-0.73^{* *}$ \\
\hline
\end{tabular}

In the third subgroup -the female group of the sporadic learners- learning seems to take place only before the class test :

Table 5 : The most important correlations between achievement in physics, ability, study habits and attitudes, and climate of the class-room for the female group of the sporadic learners $(N=40)$.

\begin{tabular}{|c|c|c|c|c|}
\hline & $\begin{array}{c}\text { Exercise } \\
\text { tests }\end{array}$ & $\begin{array}{c}\text { Intermed. } \\
\text { test }\end{array}$ & $\begin{array}{c}\text { Class } \\
\text { test } \\
\end{array}$ & $\begin{array}{c}\text { Retention } \\
\text { test }\end{array}$ \\
\hline Marks & 0.00 & -0.03 & 0.18 & 0.09 \\
\hline Piaget test & -0.12 & -0.08 & 0.36 & 0.11 \\
\hline $\begin{array}{l}\text { Phase of actualization } \\
\text { (disturbed vs. undisturbed) }\end{array}$ & -0.10 & 0.00 & $0.38^{*}$ & 0.09 \\
\hline $\begin{array}{l}\text { Achievement control } \\
\text { (capable vs. uncapable) }\end{array}$ & 0.09 & -0.23 & 0.28 & $0.42^{*}$ \\
\hline Aggression against teacher & -0.10 & -0.05 & -0.36 & $-0.40^{*}$ \\
\hline Reduced participation in instruct. & -0.03 & 0.07 & -0.34 & $-0.51^{* *}$ \\
\hline
\end{tabular}

The correlations increase in the class test and the retention test. The second block of variables reflects again a specific mixture of variables. The successful learners, who are able to reproduce learning details without difficulties and show achievement control, achieve rather good results in the last tests. The male group of sporadic learners show a similar pattern of restricted learning. As in table 5 we notice the variable reduced participation in instruction, which indicates that some students are not involved in learning physics during instruction :

Table 6 : The most important correlations between achievement in physics, ability, study habits and attitudes, and climate of the class-room for the male group of the sporadic learners $(N=35)$.

\begin{tabular}{|lcccc|}
\hline & \multicolumn{2}{c}{ Exercise } & Intermed. & \multicolumn{2}{c|}{ Class } & Retention \\
& tests & test & test & test \\
\hline Marks & 0.36 & 0.07 & 0.30 & 0.06 \\
Piaget test & $0.42^{*}$ & 0.10 & -0.07 & $0.55^{* *}$ \\
\hline
\end{tabular}




\begin{tabular}{|c|c|c|c|c|}
\hline & $\begin{array}{c}\text { Exercise } \\
\text { tests }\end{array}$ & $\begin{array}{l}\text { Intermed. } \\
\text { test }\end{array}$ & $\begin{array}{c}\text { Class } \\
\text { test }\end{array}$ & $\begin{array}{l}\text { Retention } \\
\text { test }\end{array}$ \\
\hline $\begin{array}{l}\text { Assimilation of subject matter } \\
\text { (slow vs. quick) }\end{array}$ & -0.18 & $-0.43^{*}$ & 0.12 & 0.23 \\
\hline Aggression against teacher & -0.30 & -0.14 & 0.14 & $-0.47^{*}$ \\
\hline Reduced participation in instruct. & 0.07 & -0.16 & 0.25 & $-0.41^{*}$ \\
\hline
\end{tabular}

21 The second block contains the variable assimilation of subject matter. A quick assimilation of subject matter leads to poor results in the intermediate test, since these boys are rather careless and sloppy learners.

\section{Discussion}

The study habits of the different subgroups are very different. The female group of continuous learners is adjusted to learning in school. These students learn carefully and willingly during the course. But a lack of interest demonstrates the reservation toward basic electricity. The same reservation is found in the female group of sporadic learners, too. In this subgroup the girls rely on automatic learning up to the class test. When the class test is impending, they try to reproduce learning details.

The boys find an emotional access to basic electricity via interest. The continuous learners achieve successful and persistent learning, if they are open to the new approach and if they combine their learning with interest. On the other side, the sporadic learners do not participate enough in the course. They are careless learners and forget rapidly (see table 2).

For the continuous learners constant participation in the learning processes in the classroom should be reinforced. In addition, the girls should improve their success orientation and should learn to reduce the effects of a lack of success. For the male group is important to realize that mental effort should be invested even in an interesting subject matter.

For the sporadic learners the situation is much more difficult, because they should be more active all over the teaching unit. These students often have transmissive views of learning and teaching, and passive views of their role in these processes.

The continuous learners are the allies of the teacher when the study habits and attitudes are brought up for discussion. In a more intense interaction between continuous and sporadic learners a social construction of knowledge should be possible.

\section{BIBLIOGRAPHIE}




\section{References}

HÄUSSLER, P. : Measuring students' interest in physics - design and results of a cross-sectional study in the Federal Republic of Germany, Int. Journal of Science Educ, pp. 79-92, 1987.

KOTTE, D. : Gender differences in science achievement in 10 countries, Peter Lang, Frankfurt, 1992.

LAWSON, A. E. : The development and validation of a classroom test of formal reasoning, Journal of Research in Science Teaching, pp. 11-24, 1978.

von RHÖNECCK, C. \& GROB, K. : Psychological aspects of learning about basic electricity, In Mandl, H., de Corte, E., Bennet, S. N. \& Friedrich, H. F.(eds.), Learning and Instruction, Vol. 2.2, Pergamon, Oxford, pp.589-603, 1989.

von RHÖNECCK, C. \& GROB, K. : Psychological aspects of learning about basic electricity in rural and urban classes, Int. Journal of Science Educ., pp. 87-91, 1991.

von SALDEN, M. : Sozialklima von Klassen, Peter Lang, Frankfurt, 1987.

SALOMON, G. : Beyond skill and knowledge : the role of mindfulness in learning and transfer. Paper presented at the 2. EARLI-conference, Tubingen, 1987

THIEL, R. D, KELLER, G \& BINDER, A. : Arbeitsverhalteninventar, Westermann, Braunschweig, 1979.

\section{RÉSUMÉS}

Parce que les conceptions que de nombreux étudiants ont, avant enseignement, de ce qui se passe dans des circuits électriques, se mélangent ensuite, pendant l'enseignement, avec les conceptions correctes, des difficultés particulières pendant l'apprentissage apparaissent. En vue de chercher à mieux comprendre ces processus, nous nous sommes intéressés aux résultats et aux stratégies d'apprentissage, aux caractéristiques psychologiques (intérêt, développement cognitif, façon d'étudier, attitudes) et aux interactions sociales d'étudiants de cinq classes pendant deux ans.

Since most students develop conceptions of the processes in an electric circuit before instruction and these conceptions mix during instruction with correct conceptions, special learning difficulties arise. In search of a better understanding of these processes we looked at learning results, the psychological background of the students (interest, cognitive development, study habits, attitudes) and social interactions in five classes over two years.

\section{INDEX}

Mots-clés : caractéristique psychologique, conception, électricité, stratégie d'apprentissage

\section{AUTEURS}

\section{K. GROB}

Pädagogische Hochschule Ludwigsburg, Germany 


\section{C.-V. RHÔNECK}

Pädagogische Hochschule Ludwigsburg, Germany

B. VÔLKER

Pädagogische Hochschule Ludwigsburg, Germany 